\title{
Colonial Remains in Indonesian Fashion Blogipelago
}

\author{
Galant Nanta Adhitya \& Novi Wulandari \\ galant.nanta@respati.ac.id \& noviwulandari@respati.ac.id \\ English Literature Department of Universitas Respati Yogyakarta, INDONESIA
}

\begin{abstract}
This article aims to expose the colonial remains in Indonesian fashion blogipelago. It analyzes five Indonesian fashion bloggers: Anaz Siantar's Brown Platform, Claradevi Handriatmaja's Luce Dale, as well as Olivia Lazuardy's, Ayla Dimitri's and Sonia Eryka's eponymous blogs. Since fashion blog exists in the interconnected cyberspace, this article is conducted under the scope of Transnational American Studies, approached with postcolonial theory. It then uses descriptive qualitative method in interpreting data gained from the aforementioned data, as well as the secondary ones. The finding comprises that the colonial remains are thus vividly apparent through the use of fashion blog formula by writing in English, wearing seasonal fashion, and shooting street photography abroad. This set of formulae helps Indonesian fashion bloggers to win the audience over. Therefore, the colonial remains in Indonesian fashion blogipelago are equally internalized both by the bloggers and the audience.
\end{abstract}

Article information

Received:

22 May, 2020

Revised:

12 July, 2020

Accepted:

20 July, 2020

Keywords: popular culture; post-colonialism; fashion blog; Indonesian fashion blogger

DOI: 10.24071/joll.v20i2.2611

Available at https://e-journal.usd.ac.id/index.php/JOLL/index

This work is licensed under a Creative Commons Attribution-ShareAlike 4.0 International License.

\section{Introduction}

Indonesia is a former colonized nation. Portugal, Spain, France, the United Kingdom, the Netherlands, and Japan took turns colonizing the archipelago nation for more than 400 years (AM \& Lestariningsih, 2017). This historical background affects the dynamics of the nation. Even 75 years after its independence, postcolonial discourse remains inevitable in the nation's political, cultural, and social life. This nation may be no longer under colonization physically, but its people are still heavily colonized mentally. Bressler (2011) states, "the conquerors dominated not only the physical land but also the hegemony or the ideology of the colonized peoples". Indonesians favor foreign qualities more especially coming from the West. American fast-food restaurants keep branching out in every city, Hollywood movies sell more tickets than the local ones, more European fashion brands open their stores in Indonesian malls, whitening skincare products are always in high demand, and celebrities of foreign-race descendants on national TV channels are massively idolized.

The favoritism over imported qualities worsens as the world becomes more and more globalized. The term 'imperialism' then comes to mind. While colonization involves both a "concrete act of conquest" and "direct rule" of "native people and the administration of its government, economy, and produce", imperialism is defined as "a broader form of 
authority or dominance" as well as "a larger structure of economic or political hegemony" that "continue after the end of colonial rule" in order "to exert its pressure on the ex-colonies and the "Third World", ...stresses the subordinate status of the countries to which it refers". Thus, Imperialism "helps to conceptualize both past and present forms of economic and cultural dominance" (Hiddleston, 2009, p. 2).

Moreover, the advancement of technology enables imperialism to formulate digitally anywhere and anytime. The "widening, deepening and speeding up of world-wide interconnectedness in all aspects of contemporary social life, from ...the financial to the spiritual" (Held \& McGrew, 2000, p. 2) are mediated by publication and communication sectors. Personal computers, tablets, and mobile phones are now used everywhere even in secluded, developing nations where landlines never existed. Connected to the Internet, 'brain ware' or the users of these devices can enter cyberspace or the World Wide Web (WWW). In the past two decades, the cyberspace keeps advancing, serving more features each day, from reporting news, offering omnipresent entertainments, facilitating relationships, to starting online shops. In other words, cyberspace has become an inseparable space in people's daily lives, to the extent that their way of thinking can be shifted.

Virtual and online interactivities on the cyberspace can have real impact on its users, which nowadays are equally as strong as the tangible ones. For example, online dating can end up in marriage, e-commerce transactions gone bad can lead to bankruptcy, and cyber bullying sometimes drives victims to commit suicide. As described by Ohiagu \& Okorie (2014, p. 95), "non-physical interactions and intimacies" within the cyberspace "distort other boundaries previously existing among them". Because the crisscrossing transfers in the cyberspace are impossible to thoroughly censor, the prevalent values can get tarnished, to be swamped by public taste and temporary trend (Adi, 2016). This value shift is made possible due to affect of the free-floating entity on the Internet on anyone who uses it.
One type of website that flourishes in the cyberspace due to its open-source format and user-created content (UCC) is fashion blog. Primarily considered as an online diary, any fashion enthusiast with a computer and Internet connection can start blogging about their individual fashion choices. Fashion blogs(??) contain real-time articles or posts, discussing individual clothing appropriateness, including, but not limited to, mix-and-matching of colors, patterns, and textures, as well as styling and shopping tips of seasonal items. The focal attraction of every fashion blog post is, mainly but not limited to, still pictures of the bloggers wearing their own daily head-to-toe clothes, called 'Outfit of the Day' (OOTD), shot without intervention from editor, stylist, photographer or management. Sometimes videos are also featured. The visual element is accompanied by a textual description used to elaborate the blog post title, telling the reasons behind the styling, to advise the styling tips and tricks, to describe the details of the clothing and accessories, as well as to inform where to obtain them.

As a form of fashion media, fashion blog is often compared to, or even dubbed as the disruptive innovation of, the fashion magazine, yet its affiliate and hyperlink features resemble a brand-owned website. What greatly differentiates fashion blog from fashion magazine and corporate websites is its comments section. Fashion bloggers can share their personal styles to unlimited audiences worldwide, who in turn can give their opinions or questions in the allocated comments section. The comments section thus encourages bloggers and audiences to interact with one another. Their crisscrossing interaction creates, according to Dean (2010, p. 38), a "blogipelago". It is analogous as each blog possesses "separateness" requiring both bloggers and audience an "immense effort ...to move from one island or network to another" in order to "attend to the variety of uses, engagements, performances, and intensities blogging contributes and circulates".

Fashion blog originated in the United States with the creation of She She Me and Primp in 2001, followed by DFR: Daily 
Fashion Report in 2002 and No Good for Me in 2003 (Rocamora, 2011). More fashion blogs soon emerged abroad. The phenomenon reached France in 2005, with the emergence of Garance Doré's Atelier Doré and Danielle Meder's Final Fashion, then stretched to the United Kingdom in 2006, with the presence of Susie Lau's Style Bubble as well as Michelle Haswell and Marie Thomson's Kingdom of Style. In the same year, a blogging search engine Technorati (in Corcoran, 2006) estimated two million fashion-and-shoppingrelated blogs dispersed in the cyberspace. The number quickly multiplied when personalstyle community websites, such as Chictopia and Lookbook were created. In these two sites, Indonesian fashion bloggers first appeared, with the likes of Cindy Karmoko, Ario Achda, Wisnu Genu, and Jovi Adhiguna.

Indonesian fashion blogipelago grew after their Western counterparts have made impacts in as well as gained recognitions from the insiders of fashion industry. Blogging henceforth began to be seen as a reputable career. Following their Western counterparts in establishing independent blogs, e.g., Wendy Nguyen's Wendy's Lookbook, Blair Eadie's The Atlantic Pacific, Adam Gallagher's I Am Gala, and Tina Leung's Bagsnob, Indonesian fashion bloggers then also moved from free community websites to independent blogs; e.g., Diana Rikasari's Hot Chocolate \& Mint, Evita Nuh's Jelly Jelly Beans, Keshia Nathania's Banana Lace, Indah Nada Puspita's Sketches of Mind, as well as Tysna Saputra's and Aquinaldo Adrian's eponymous blogs. Since then, they started making waves across the local fashion industries, receiving frontrow invitations at fashion shows, headlining brand campaigns, being brand spokespersons, and collaborating in releasing capsule collections. In the United States alone, Mediakix, a Californian-based marketing agency, estimates the marketing capital on fashion blogs to be around $\$ 1$ billion (Berezhna, 2018). This promising financial success tempted more aspiring bloggers to try their luck.

The mushrooming effect of fashion blog is encouraging as blogging, predominantly a pastime activity, categorically belongs to popular culture. As popular culture has the power to reflect the needs and wishes of the people, fashion blog then becomes a source of entertainment, information, and even education for their devoted audience. Due its existence in the cyberspace, fashion blog can be easily accessed anytime and anywhere for free, making its contents insinuate widely, quickly, and deeply. In addition, fashion blog also is free cyberspace open for public participation for bloggers and audience alike. Toffler (1980, p. 282) coins the term "prosumer", which is a portmanteau of the words: 'producer' and 'consumer'. The lines between producers and consumers are merged and blurred, which is the main characteristic of the Web 2.0. Fashion blog audience are not merely passive recipients, as they also have the same opportunity to be active producers by posting contents in their own blogs.

Previously, the blogger-audience relation was examined by L. Durmaz (2014) in "The Role of Social Media in the Fashion Industry: How Fashion Blogging Encourages Two-Way Symmetrical Communication". Meanwhile, "The Megaphone Effect: Taste and Audience in Fashion Blogging" by E. F. McQuarrie, J. Miller and B. J. Philip (2013) highlighted the domino repercussions of fashion blog contents. Furthermore, M. Titton (2015) wrote "Fashion Personae: Self-identity and Enactments of Fashion Narratives in Fashion Blogs" to analyze how fashion bloggers formulate their own self-representation, which in turn affect how the audience receive their narrative. It is clearly seen that the needs for a cultural analysis on fashion blogs still exist, especially on their roles to the changing fashion industry during the globalization era. This article thus focuses on the transfer of influence in the globalized world.

Considering Indonesia's colonial background and the Western origin of fashion blog, this research focuses on postcolonial discourse in Indonesian fashion blogipelago. As fashion blog is a UCC, Indonesian fashion blogipelago speaks volumes about its bloggers. From the perspective of postcolonial studies, this article aims to discover whether there are colonial remains influencing Indonesian fashion bloggers during the 
production process, and if so, how they are embedded in the blogs. Given that the Internet is often assumed as a medium of imperialism to transpire digitally, this article aims to see whether the colonial remains have led to either the success or the failure of the bloggers. Since the analysis of popular culture cannot be separated from its audience and with comment section being allocated, these objectives are expected to give a broad depiction regarding the postcolonial state of Indonesian people in the cyberspace as well.

\section{Methodology}

This article deals with the issue of postcolonial discourse within Indonesian fashion blogipelago. There are two types of data, i.e., primary and secondary data. The primary data are taken from Witjaksono's piece in Indonesian Tatler (2016). The article was chosen because the magazine is a branch of world-renowned lifestyle magazine, Tatler. There are five Indonesian fashion bloggers listed in it, which are,

Table 1. List of Chosen Fashion Blogs

\begin{tabular}{|c|l|l|l|}
\hline No. & \multicolumn{1}{|c|}{ Blogger } & \multicolumn{1}{c|}{ Blog } & \multicolumn{1}{c|}{ Blog Address } \\
\hline 1. & Anaz Siantar & Brown Platform & http://www.brownplatform.com \\
\hline 2. & Claradevi Handriatmaja & Luce Dale & https://www.lucedale.co \\
\hline 3. & Olivia Lazuardy & Olivia Lazuardy & http://olivialazuardy.com \\
\hline 4. & Ayla Dimitri & Ayla Dimitri & https://ayladimitri.wordpress.com \\
\hline 5. & Sonia Eryka & Sonia Eryka & https://soniaeryka.blogspot.com \\
\hline
\end{tabular}

As these "top-notch online influencers" are the ones that Indonesians look up to when seeking fashion inspirations, they are likely to look for inspirations elsewhere. Analyzing what inspires the inspirers is thus hoped to provide a comprehensive understanding whether this effort is affected by the fact that Indonesians are ex-colonized.

Supplementary to the aforementioned blogs, other fashion blogs, as well as various sources in books, journal, news articles, and website related with the discussed topic, as secondary data. Since the data are in form of textual elements: words, phrases, sentences and paragraphs; as well as visual elements: pictures and screenshots, this non-numerical article employs qualitative method. Creswell (2014, pp. 212-4) defines qualitative method as,

... a form of interpretive inquiry in which researchers make an interpretation of what they see, hear, and understand. Their interpretations cannot be separated from their own backgrounds, history, contexts, and prior understandings. ...With these concerns in mind, inquirers explicitly identify reflexively their biases, values, and personal background, such as gender, history, culture, and socioeconomic status that may shape their interpretations formed during a research. The data are collected, clustered and interpreted subjectively, to then being presented descriptively.

Furthermore, this article uses a deductive approach. It derives from a hypothesis based on a series of facts subjectively assessed from a set of theoretical framework on postcolonialism to arrive at a comprehensive conclusion regarding the realm of Indonesian fashion blogipelago. As a type of website on cyberspace, blog becomes a medium for worldwide interactions. This article thus technically falls under the scope of Transnational American Studies. According to Vetrovec (1999, p. 2),

Transnational American Studies describes a condition in which, despite great distances and notwithstanding the presence of international borders (and all the laws, regulations and national narratives they represent), certain kinds of relationship have been globally intensified and now take place paradoxically in a planet-spanning yet common-however virtual-arena of activity. 
Transnational American Studies is a contemporary school of thought. In that sense alone, it is at the very cutting edge of present academic inquiries. With its global reach, it highlights the crisscrossing and never-ending exchanges of information and communication pioneered and/or acquired by the United States. As stated by Fishkin (2005, p. 43),

The United States is and has always been a transnational crossroads of cultures. ...Reading Thoreau helped inspire Gandhi to develop his own brand of civil disobedience, which crossed the Pacific to inspire the civil right movement; the idea of dissent through civil disobedience as particularly American resurfaced in Asia when Tiananmen Square protesters used the Statue of Liberty as a symbol".

The expanse and export of American commodities bring along with them the values and customs of American culture. Therefore, the social, political and economic aspects of the world get more and more interconnected among societies and communities. Transnational American Studies facilitates people in any part of the world experiencing this interconnectedness to scrutinize it. Rowe (2014, p. 1) then specifies that,

Transnationalism' also refers to American studies done by international scholars outside the U.S., especially scholarship that emphasizes the influence of the U.S. abroad...transnationalism is closely connected with the study of European imperialism and its postcolonial effects in the nations and societies of the Western Hemisphere.

The United States holds a unique position. Besides as an ex-British colony, its history of slavery, its mistreatment towards Native Americans and its invasion of multiple parts of the world are considered as colonial practices. This fact not only provides a bedrock stance to analyze the impacts of American expansion and exportation on a global level, but also puts them as a window to elucidate the repercussions of Western colonization.
Alongside Transnational American Studies, Postcolonial theory is also employed due to its extensive investigation to intercultural exchanges, and its critical search for answers to power relation in various contexts. Explained by Burney (2012, p. 42),

Postcolonial theory is used between and across disciplines as a critical tool for deconstructing the underlying layers, structures, and forms that are embedded in the colonial past and postcolonial present. Wide-ranging issues relating nationalism, history, socioeconomics, geopolitics, and international relations have all been critiqued through the critical lens of postcolonial theory, deploying its methodology of close reading and discourse analysis.

Postcolonial critique sees colonization as a continuous process, which begins with the forming of empire in the West up to the aftermaths of colonization on the rest of the world, including the developmental changes throughout the whole ordeals. In the same vein, Ramutsindela $(2005$, p. 1) emphasizes,

...the trilogy of history-pre-colonial, colonial and post-colonial-implied in the word post-colonialism as an intermixture of events, processes and actors that transcends any form of periodisation. In other words, it acknowledges the continuing domination of postcolonial societies by former colonial masters in one form or another.

The hardship of being colonized deeply influenced the ex-colonized. Past colonial institutional and educational systems linger, governing their decision makings upon development and modernization. As a result, Western remains are still habitually found in the present-day state of the ex-colonies.

In addition, postcolonial critique draws "connections among all the domains of our experience-the psychological, ideological, social, political, intellectual, and aesthetic-in ways that show us just how inseparable these categories are in our lived experience of ourselves and our world" (Tyson, 2006, p. 417). It can do so both "at the local level of ex- 
colonial societies as well as at the level of more general global developments" (Quayson, 2000, p. 4). Forms of global developments in the past three decades have been fundamentally leaning toward digital innovations. Helton (2002) considers the Internet particularly to have transformed the world on the same level as the Industrial Revolution in the late $18^{\text {th }}$ to early $19^{\text {th }}$ century, where traditional lives were left behind because manual-laborers were replaced with modern machineries. While some of the resulted transformations are technical, some others are significantly cultural.

Even more so, the Internet carries out "political and economic power to exalt and spread the values and habits of a foreign culture at the expense of a native culture" (Bullock \& Stallybrass, 1977, p. 303). The Internet thus contributes greatly to the cultural imperialism ubiquitously occurring nowadays. According to Shabazz (1999, p. 27),

The Internet was founded as a "Cold War" project by the Department of Defense to thwart efforts of a Soviet surgical strike and subsequent destruction of the information infrastructure. Therefore, it is appropriate to say that the construction of the Internet was based on political motives. The Internet has changed the nature of international relations and diplomacy by rendering the linearity of time and vastness of space as less significant factors.

The political implication of the Internet is supported by Jandrić \& Kuzmanić (2015, pp. 35-39), arguing that "technology and colonialism are dialectically intertwined", in the way they deal with extensification as well as exploration of "new frontiers, new challenges, and new perspectives". The expansion and exportation through the Internet mimic colonialism, especially for the ex-colonized. Although there is no colonial subjugation, such as "a concrete process of invasion and a practical seizing of control" (Hiddleston, 2009, p. 2) over lands, digital imperialism exists because the majority of advantageous space is inhabited and mastered by the West (Laric, 2010). From the beginning, the formation of cyberspace has generated a divide within its users even as it has made possible degrees and types of communication hitherto impossible.

Technological infrastructures, from hardware to software, are developed and made by Western nations to then build for and/or in the rest of the world. For instance, 02, Vodafone, Axis, Yandex, and Spotify are from European nations, while Microsoft, Apple, Google, Facebook, and Amazon are from the United States. These networks, devices and services are used globally, the West thus have the upper hand in cyberspace. Kim (1998, p. 2) divides the dichotomy of cyberspace based on,

'core and periphery' theories, the core consists of "rich" and "industrialized" countries of the "First World," whereas the periphery includes "poorer" and "rural countries in the "Third World" ... "information and technology are controlled by core nations and flow is unidirectional, from core to periphery, with little opportunity for peripheral nations to participate in the process".

Digital imperialism is the transfer of the remaining postcolonial social relationships from physical lands to virtual cyberspace. During the process of settlement, the colonizer co-habits with the colonized. This dialectical encounter has shaped the power dynamic among them. Drawing upon the relation between the olden colonization and digital imperialism, technology inventors, (e.g., Bill Gates, Tim Berners Lee, Steve Jobs, and Mark Zuckerberg), can be considered as present-day equivalent to the ancient seafarers, (e.g., Christopher Columbus, James Cook, Alfonso de Albuquerque, and Amerigo Vespucci). This parallelism supports Fanon's theory (2001) that colonizers are the ones who established the colonized territories. Prior to their discoveries, cyberspace is "lifeless, empty, non-existent" without the "pre-existing natives", so "the new savages are sought for and created elsewhere ...from peoples who are left behind in the old territories" (Jandrić \& Kuzmanić, 2015, pp. 42-43). 
The virtual divide is thus as real as any other social gaps (e.g., wealth gap, racial segregation, and gender inequality). Cyberspace is then assumed to be the relocation of the prevailing inequalities. Designated by the West, it "serves as a tool of thought and of action" and "a means of control, and hence of domination, of power" (Lefebvre, 1991, p. 20), which makes it prone to white supremacy and race-based discrimination (Risam, 2013). Therefore, the behavior and attitude of its users are easily affected by information and ideas spreading remotely and quickly via the Internet. Consequently, this cyber domination emits Western influences to the rest of the world. While the West is thought of as "the model of 'developed' completeness", the rest refers to the term 'Third World', "lacking, wanting, incomplete, and underdeveloped", thus "in need of the wealth and expertise of the 'West' to help resolve its many 'problems' ...the object of the 'West's' pity" (Du Bois in Phillpott, 2000, p. 48).

As a conduit of cultural imperialism, nations that possess control over the invention and innovation of technology are accordingly in control over the direction of the world's resources. This dichotomous disparity between the developed and developing nations allows the West to accumulate power over the non-Western societies and their people. As stated by Kraidy (2002, p. 359), "audiences across the globe are heavily affected by media messages emanating from the Western industrialized countries". The constant cultural penetration from the West has significance in formulating the sense of self, both in the personal and communal lives of the ex-colonized. Under the term "the generalized other", Mead (1967, p. 140 ) elucidates the self as "essentially a social structure" which "arises in social experience". The self thus can only be constructed when the person implements the standpoint of 'the other' when looking at himself or herself (Mead in Whittaker, 2008, p. 54).

To make matters worse, at the severe degree of colonialization, the colonizers realized that they could benefit more out of the colonized if they were more civilized, educated, and skilled. These improvements were permissible with the proviso they were kept under the desired restrains of the colonization that governed both of them (ibid., p. 86). In view of that, the "colonial difference, cultural or racial, returns the eye of power to some prior archaic image or identity", the ex-colonized thus "can neither be 'original'-by virtue of the act of repetition that constructs it-nor identical-by virtue of the difference that defines it" (ibid., p. 153). Conflicted with the experience of Western colonization, the colonized self will either be conceding or opposing to Western qualities. As noted by Bhabha (1994, pp. 168-9),

...the colonial presence is always ambivalent, split between its appearance as original and authoritative and its appearance as original and authoritative and its articulation as repetition and difference.' It is this ambivalence that makes the boundaries of colonial positionality-the division of self/other and the question of colonial power-the differentiation of colonizer/colonized.

This notion of ambivalence confuses the ex-colonized when forming their identity; due to the duality between their own cultural identity and the colonizer's cultural identity. It then leads into the act of mimicry. Mimicry refers to the performance of the colonized imitating or mimicking the colonizers and their cultures. However, the colonized are only "almost the same, but not quite" as the colonizers (ibid., p. 131). This postcolonial reality prevails and explains why belatedness becomes a characteristic of ex-colonies. It is because the center of modernity and progress are thought to recline in the hands of the Western nations.

As the pioneer of fashion blog, what Western bloggers display are followed by the worldwide counterparts, to the extent that they have become fashion blog formula. Described by Cawelti (1977), formula is a set of generalizing the characteristics of large groups of individual works from certain combinations of cultural materials and archetypal story pattern. It is useful primarily as a means of making historical and cultural inferences about the collective fantasies shared by large groups of people and of 
identifying differences in these fantasies from one culture or period to another.

\section{Results and Discussion}

The fact that fashion blog first emanated in the West renders its formula to be of Western characteristics. Despite geographical distance, the fashion blog formula can be greatly felt throughout Indonesian fashion blogipelago. Unwittingly, it is intensified due to the colonial background of the nation. From the textual to visual elements, as well as the clothes shown are all heavily influenced by the West. The colonial remains are thus vividly apparent through the use of language, seasonal fashion, as well as photography.

\section{Writing in English}

The vast majority of computerization and virtualization are conveyed in English, since it is the universal lingua franca. As language is the medium of communication that cuts to the visceral depth of the psyche, the use of English is regarded as a vehicle of digital imperialism. Fashion blog is a nonauthoritative cyberspace where one has the luxury to construct every feature, including its textual feature. Nonetheless, even the nonAnglophone fashion bloggers write in English, instead of their mother tongue. To put it in perspective, fashion magazine franchises use the local language, e.g., Marie Claire Indonesia, Elle Indonesia and Harper's Bazaar Indonesia are all written in Bahasa Indonesia. Therefore, the use of English as a personal preference of the Indonesian fashion bloggers can be said to have been driven by their ex-colonized mindset. They then choose to name their blogs as well as give blogpost titles and descriptions in English, demonstrated as follows.

The use of formulaic element is useful as a means of making historical and cultural inferences about the collective conceptions shared by large groups of people differ from one culture or period to another. Moreover, fashion blog has a "snowball effect". Its contents that in the beginning only have a little importance can grow into a bigger state of significance because they are being reshared easily both by other bloggers and audience at a fast pace, i.e., "viral" (de Brouwer \& Dekker, 2014, p. 7). By analyzing the Indonesian fashion blogipelago, these methodology, theoretical framework, and data collection are able to yield thorough findings regarding colonial remains in Indonesian fashion blogipelago and Indonesian people in general as ex-colonized. 
Figure 1. The Use of English on_Sonia Eryka
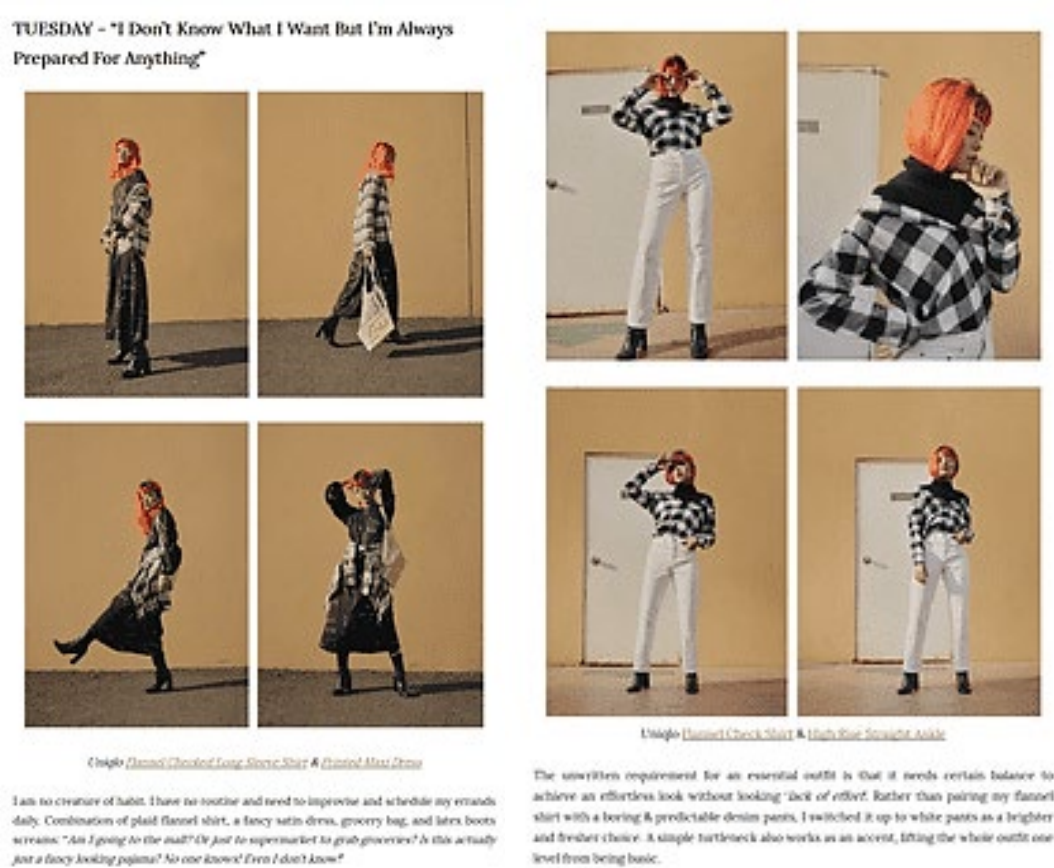

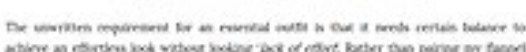

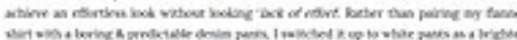

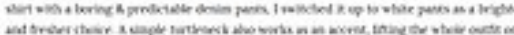

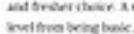
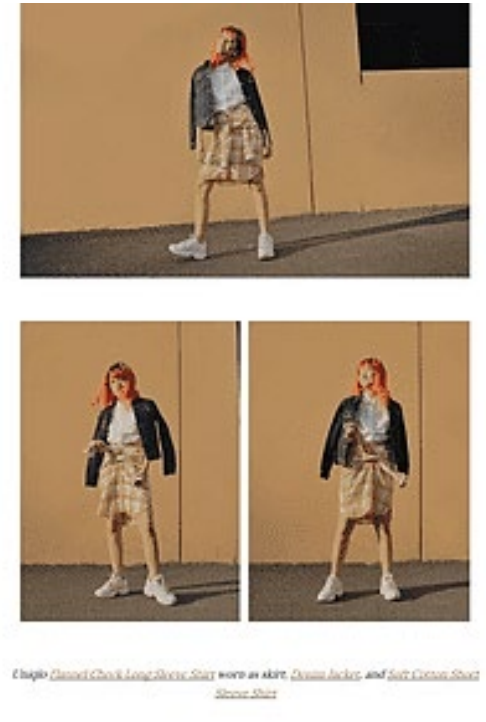

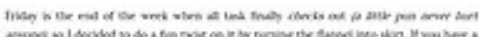

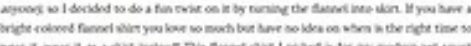

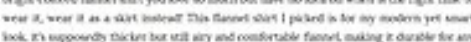

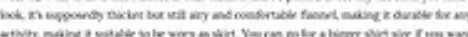

Eryka is one of the earliest Indonesian fashion bloggers. Prior to making her mark in Indonesian fashion blogosphere, she was a child actress and singer. When she reached teenage years, she created a Lookbook account to express her love for fashion. As an actress/singer, she was only known locally. Yet as a fashion blogger, she gathered wider recognition. Because the website is Americanbased, all of her Lookbook posts are by design written in English. However, upon establishing her own blog in 2011, she keeps telling her fashion journeys as well as giving fashion tips and tricks in English, (see Figure 1).
In Indonesia, and other countries where English is not the mother tongue, one's mastery of English is related to their social status. Those who speak English fluently are considered to come from affluent families and possess higher intellectuality (Onishi, 2010). It results in Bahasa Indonesia considered as a language of the second class. Many Indonesian people are even boastful when speaking their own mother tongue in a stuttering manner. The excessive pride in using English seamlessly transmits from the bloggers to their audience, as noticeable in the following figure. 
Figure 2. The Use of English on Brown Platform
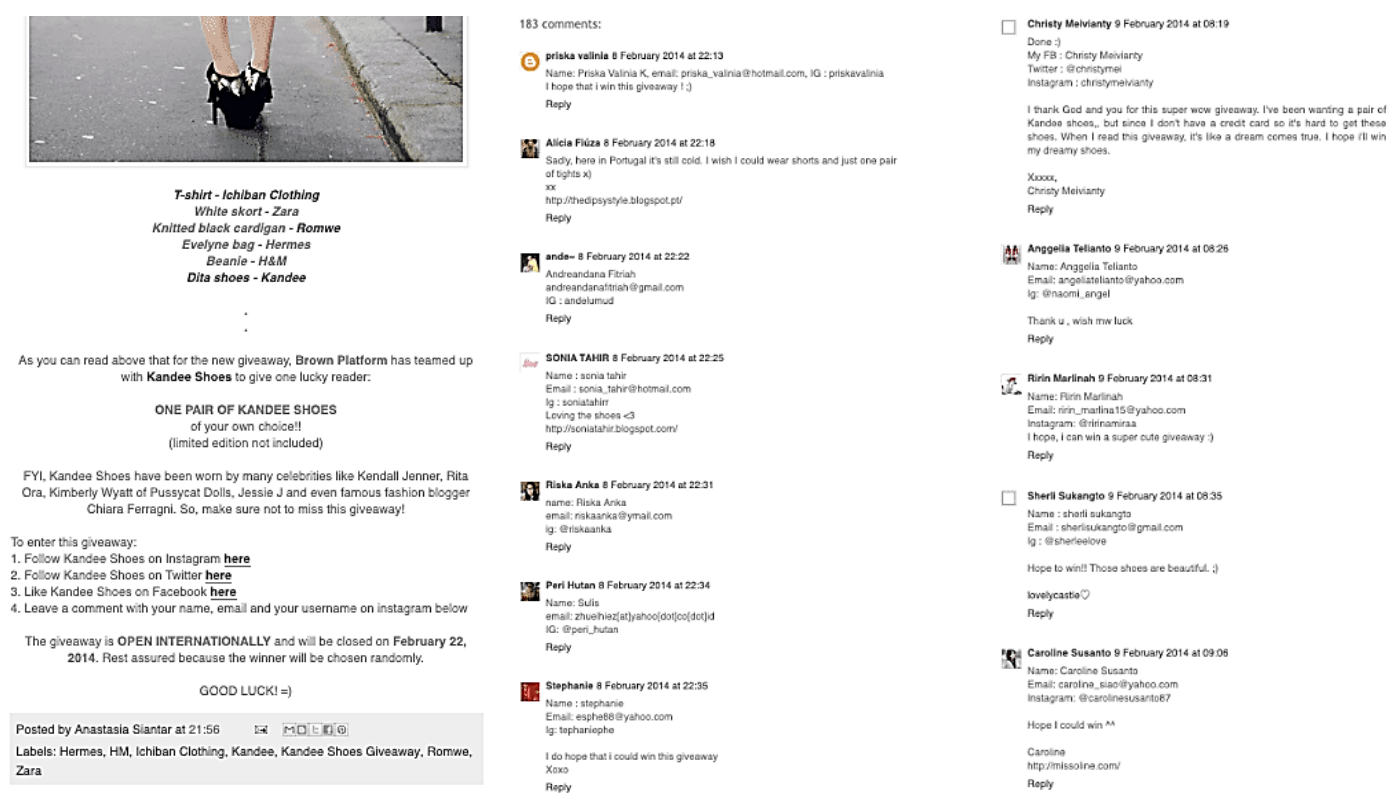

Since the Indonesian beloved fashion bloggers write in English, so do their devoted audience. The comments in the Indonesian fashion blogs are mostly written in English, as spotted in one of Siantar's blogpost (see Figure 2). Although the commenters' user IDs are of Indonesian names, none of them write in Bahasa Indonesia. It shows that the use of English as a colonial remain in Indonesian fashion blogipelago is not only strengthened

by the bloggers, but also extended by the audience. The UCC nature of fashion blog encourages the Indonesian audience to be fashion bloggers too. After witnessing the success that Siantar has reached, English becomes their language of choice. Regardless of how imperfect their competency might be, Indonesian fashion bloggers insist on writing in English, as seen below.

Figure 3. The Use of English on Aquinaldo Adrian
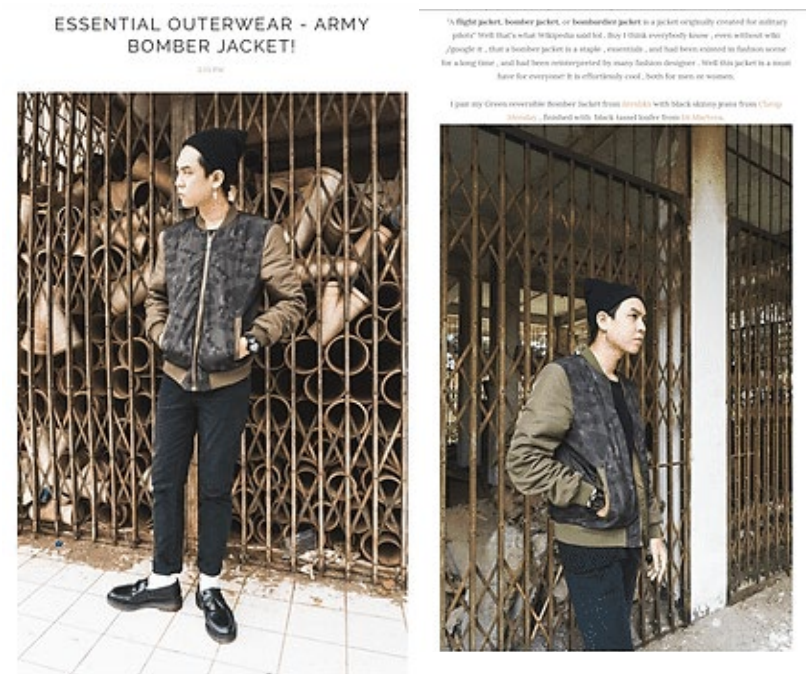
There is several tense inaccuracy and grammatical errors easily observed in Adrian's blogpost (see Figure 3). He writes "that's what Wikipedia said" instead of "that's what Wikipedia says"; "everybody know" instead of "everybody knows"; "a bomber jacket is a staple, essentials" instead of "a bomber jacket is a staple essential"; "had been existed in fashion scene for a long time, and had been reinterpreted by many fashion designer" instead of "have existed in fashion scene for a long time, and have been reinterpreted by many fashion designers"; as well as "black tassel loafer" instead of "black tassel loafers". The fact that his English inadequacy does not stop him from wiring in English signifies his belief that English, as a Western quality, can somehow position himself above other bloggers in the Indonesian fashion blogipelago, and put himself alongside Western fashion bloggers.

The pervasive use of English has eroding impacts on Bahasa Indonesia. Indonesians study English attributable to its perceivedhigher status. Upper-middle-class Indonesians also prefer their children to enroll at international private schools, where English is used as the primary language during daily class activities. Many children thus only speak Bahasa Indonesia poorly. In extreme cases, the grandchildren living in a household together with their grandparents cannot even communicate with one another because they do not learn the mother tongue. Similar to many native vernaculars in the brink of extinction, it is obvious that the textual element of Indonesian fashion blogipelago put Indonesian lingua legacy under a serious threat.

\section{Wearing Seasonal Fashion}

There are two seasons in fashion, called Spring/Summer and Fall/Winter. Collection from each season is introduced twice a year during fashion weeks in New York, London, Paris and Milan. In February and March, highend fashion brands showcase their Fall/Winter collection for the upcoming fall, whereas their Spring/Summer collection for the next year's spring is presented in September and October. Spring/Summer collection is sold from January to June, and Fall/Winter collection can be purchased from July to December. As an instance, 2019/2020 Louis Vuitton Fall/Winter show was held on March 5, 2019, while the collection became available to purchase by July 2019 . Established by Western countries in the northern hemisphere, this fashion calendar was not to intend merely to reflect climate factors, but also to generate sales. This system is then spread globally, including in tropical countries that only have two seasons.

Indonesia is located right in the equator line, thus it only has dry and rainy seasons, with temperatures and humidity more or less constant throughout the year. This geographical location does not stop local fashion bloggers from applying the Western seasonal fashion on their postings. Spring/Summer collection is manufactured with light textiles and is still wearable in Indonesian weather. Likewise, clothes made of thicker fabrics can be worn during the rainy months. In spite of that, there is no functional need for Indonesians to wear clothes primarily targeted for snowy countries. Although the average temperature in Indonesia ranges from $18.2^{\circ} \mathrm{C}$ to $40.3^{\circ} \mathrm{C}$ in 2014 (Badan Pusat Statistik, 2017), local bloggers insist on wearing Fall/Winter collection, as displayed below. 
Figure 4. Seasonal Fashion on Luce Dale

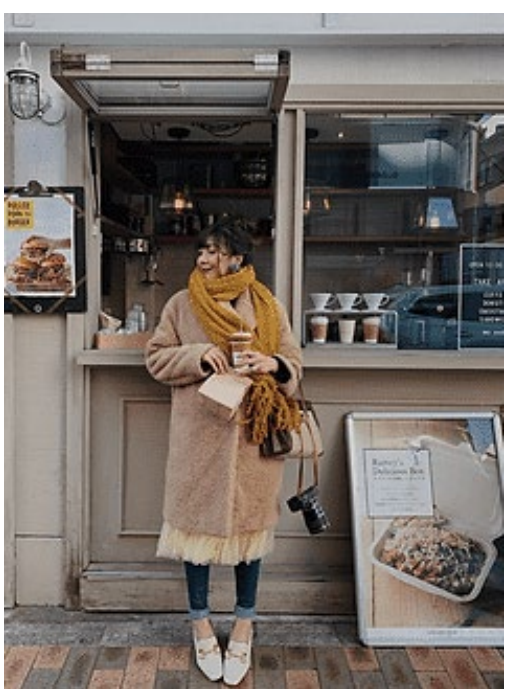

On the left photo, Handriatmaja wears a khaki coat on top of her yellow tulle dress, and wraps a camel shawl around her neck. Still with the same color scheme, she opts for a crème with a pair of black wide-legged pants and a black military coat on the right photo (see Figure 4). Besides the earthy color palette, the layering is a characteristic of Fall/Winter fashion. To beat the frosty air, at least four layers of clothing are worn at the same time. Fall/Winter collection thus has more variety to offer with designs using rich materials, making the Fall/Winter items more expensive (Pustetto, 2011). For Indonesian fashion bloggers, despite the non-existence of leaves falling and temperature dropping, they will still be getting a whole new wardrobe. Not only would they rather sacrifice comfort at the expense of flaunting weighty pieces of weatherproof attire, they also willingly splurge a large sum of money. Such act

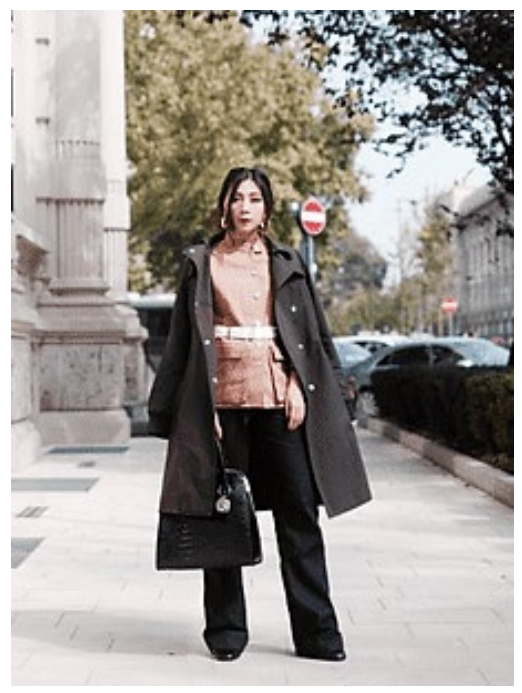

reflects a "conspicuous consumption", which refers to the habit of taste and consumption (Veblen, 1899, p. 33). The value of clothing does not lie in its functionality, but in the social status it bestows or, in Tyson's term, "sign-exchange value" (2006, p. 62). Disregarding functionality, Indonesian fashion bloggers go to great lengths to flaunt Fall/Winter clothes in order to gain admiration from their audience, since the collection has Western qualities with which they are enchanted.

The enchantment over Western seasonal fashion is also perceptible from the display of Pre-Fall and Pre-Spring. These pre-collections are created to shorten the wait and warm the consumers up ahead of new main collections. This way brands can ensure their retail stores are never left empty, and thus continuously make profits.

Figure 5. Fashion Calendar

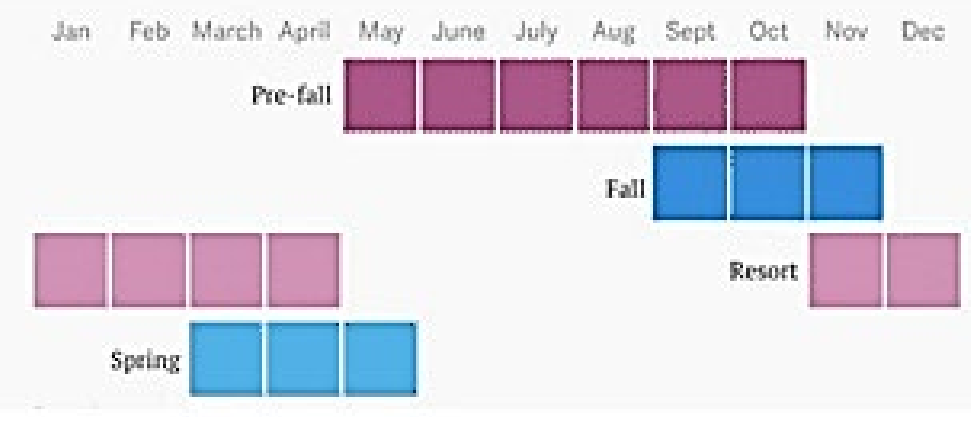


As illustrated by Dhillon (2018) in Figure 5, Pre-Fall and Pre-Spring collections last on the shelves twice as long as the biannual main seasonal collections. Pre-Fall collection is sold in May until October to take advantage of the consumers who have just come home from summer vacation and/or go back to school. Meanwhile, Pre-Spring collection arrives in stores by November and stays through April to capitalize on travelers who aim to escape the cold during Christmas and New Year holiday.
The Pre-Spring collection is also known as Cruise or Resort, intended to be sported onboard a cruise ship with destination to resorts in the tropics. Chanel was the first fashion brand to create Cruise collection back in 1919 for their wealthy consumers who could afford vacationing outside of the usual period on a trip across the globe taking voyages to tropical countries. Other Western fashion brands immediately followed suit. The Western-based fashion bloggers have always been seen wearing the collection, which is then replicated by Indonesian fashion bloggers.

Figure 6. Seasonal Fashion on Brown Platform

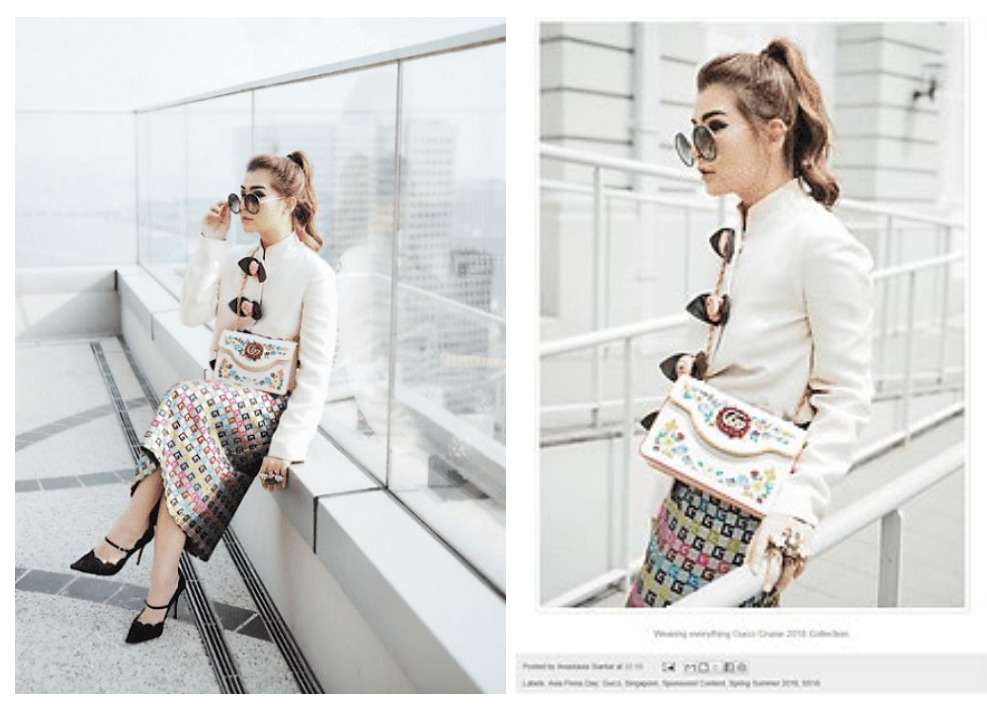

In Indonesia, the temperature difference in the trans-seasonal weather, from rainy to dry, or vice versa, is not glaringly contrast. Indonesians thus do not need a whole wardrobe change every season. However, the trans-seasonal collections can be seen in Indonesian fashion blogipelago. One of them is Siantar, clad in Gucci Cruise 2018 collection (see Figure 6). Ineptly, her OOTD is not photographed in line with the reason why the collection was created (i.e., sailing on a cruise or 'staycationing' in a resort. This fact indicates that the collection is not served by Indonesian fashion blogger for its functionality, but rather for its sign-exchange value.
Additionally, it is unfortunate that the stylish realm that Indonesian fashion bloggers feel upon wearing seasonal fashion as one of Western qualities is enforced by the excolonized mindset. As stated by the likes of Fanon, Spivak, and Bhabha, from the postcolonial perspective, "subversion is encapsulated in mimicry and this seems to characterize contemporary Indonesian fashion, intertwined with a degree of ironic self-orientalizing and exoticization in the context of a liquid modernity" (Lopez y Royo, 2019 , p. xxviii). The colonial remain somehow assigns seasonal fashion to be a necessity. While the fashion calendar of brands' releases their collections for commercial reason, the colonial remain of Indonesian people makes 
them easier to be led further into consumerism.

\section{Shooting Street Photography Abroad}

Fashion blog approaches fashion through a more personal lens. It focuses equally on both the clothes and the wearer. The clothes are worn, styled, shot and curated by the bloggers themselves. This UCC system results in a more organic outcome. Fashion blog thus centralizes on what the bloggers truly wear. This personal approach to fashion is emphasized on the OOTD photos by the use of street photography. Street photography captures spontaneous moments outdoor in public places. Fashion bloggers then shoot their OOTDs on the open-air cityscapes with buildings, stores, cafés, parks, hallways, and bridges in the backgrounds. Notwithstanding the system that should have been given bloggers total freedom and control over the content production, Indonesian fashion bloggers are still fixated on their Western counterparts. Therefore, the street photography of their OOTDs, which could have been taken anywhere actually, are taken abroad, as often seen in Lazuardy's blogposts.

\section{Figure 7. Street Photography on Olivia Lazuardy}
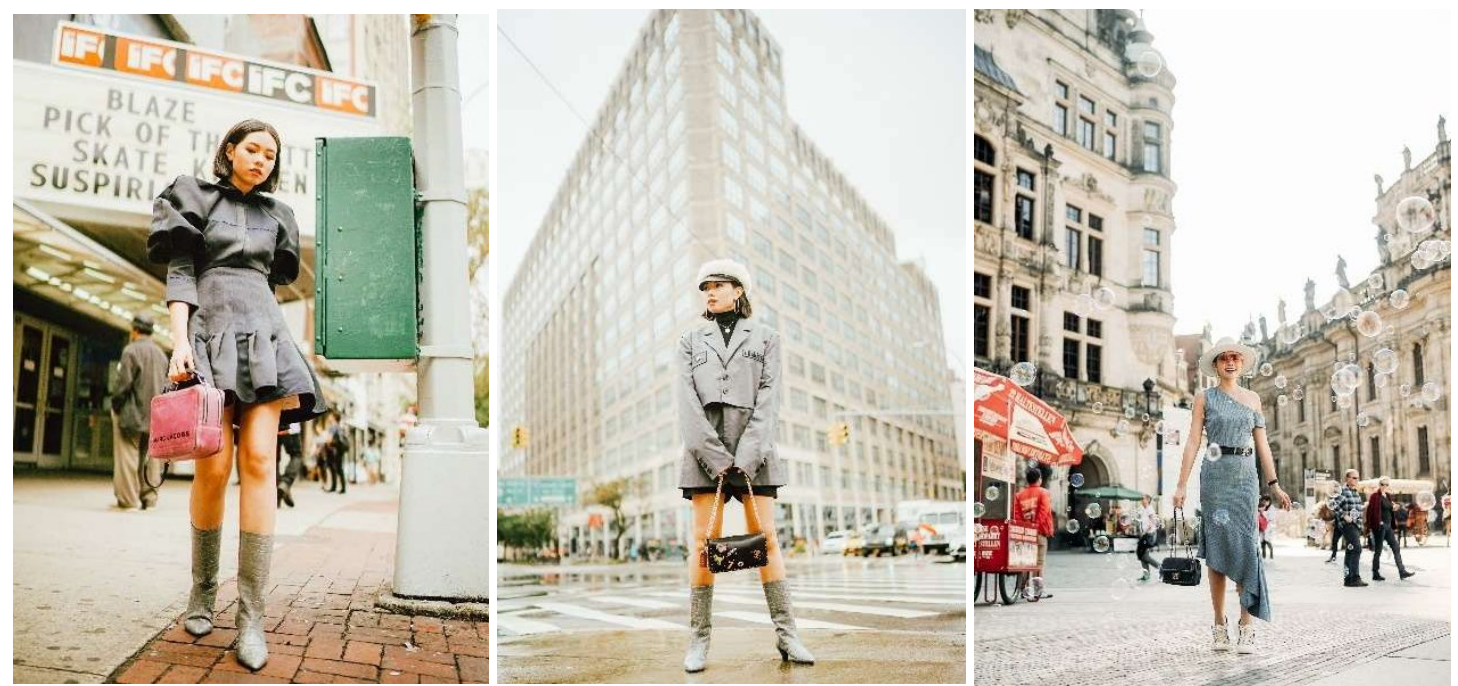

Lazuardy is an Indonesian-born fashion blogger based in Jakarta. Nevertheless, only a handful of blogposts contain photos taken in the city, or even in the country. Her OOTD photos are almost entirely taken abroad. The streets of New York, Paris, Milan, and London become recurring locations on her blog (see Figure 7). She is either transfixed on the formula of Western fashion blogs or fascinated by the urban environments abroad that are more scenic. It can be said that the colonial remain makes her reluctant to take photos in her own country.

Moreover, the foreign qualities of her OOTDs are intended to entice a larger audience. This estimation turns out to be accurate as they receive more exposure. For instance, there are more engagements (e.g., likes, comments, shares and subscriptions) on the posts whose photos are shot abroad than the ones shot inside the country. It then can be said that the colonial remain in term of favoring Western qualities are equally possessed both by the bloggers as well as their audience. Either because Indonesian audience first see the Western bloggers and assign them as standard or because they are impressed by bloggers who are able to travel the world, the pervasive portrayals of street photography abroad can be obviously seen as a form of colonial remains.

Ideally, OOTD photos are intended to create an impression that these clothes are worn by the bloggers walking around in 
foreign cities. Due to this purpose, the OOTDs must appear to have been taken organically without too much preparation or editing. The OOTDs are thus shot in the daytime, taking advantage of natural lighting from the sun. Moreover, as the photography in Indonesian fashion blogipelago revolves around the bloggers travelling abroad, they are often photographed carrying what they consume, such as coffee. Fashion bloggers are often photographed with a cup of coffee on their hand, as a feature purposely caught on camera to appear as if they are just doing their daily routine. However, it is not just any coffee sold at any local shops that they drink from. Instead, it is Starbucks cups that they are seen holding.

Figure 8. Street Photography on Ayla Dimitri
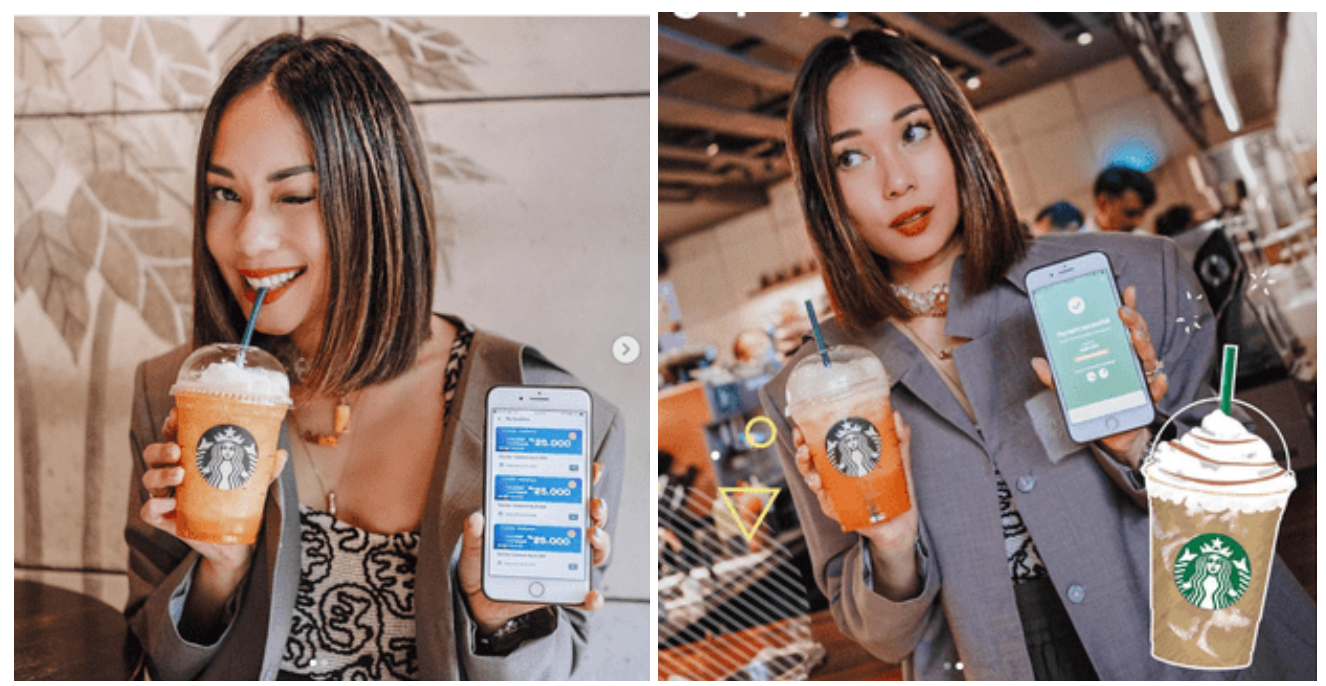

Stated by the International Coffee Organization (2019), Indonesia is one of the biggest coffee producers in the world. Despite that fact, Starbucks is still more favorable over local coffee shops since it is a foreign coffee brand. Collectively, Indonesia as a society ascribes a higher pride on products imported from abroad, specifically the West. Drinking Starbucks abroad is thus a matter of social status. Being photographed with Starbucks coffee has thus become a commodification practice for its signexchange value. Featuring the Starbucks cup is then imitated by the audience of Indonesian fashion bloggers. In the long run, they voluntarily imitate the bloggers by sharing photos with Starbucks drinks in their hand, snowballing this colonial remain broader within the Indonesian audience. In order to accompany her O0TDs, Dimitri, as seen on Figure 8, appends close up photos of her holding a Starbucks drink.

\section{Conclusion}

Analyzed through Transnational American Studies, the colonial remains in Indonesian fashion blogipelago are thus vividly apparent through the use of fashion blog formula initiated by Western-based fashion bloggers. When composing their blogposts, Indonesian fashion bloggers follow the formula by writing in English, instead of Bahasa Indonesia; wearing biannual and trans-seasonal fashion; and shooting street photography on the streets of foreign cities. With these formulaic elements, Indonesian fashion bloggers are then able to attract the audience. As their success is shown by audience numbers, it indicates that the colonial remains in Indonesian fashion blogipelago are equally possessed both by the bloggers as well as the audience. It can be concluded that fashion blog has become a space of digital colonialism.

Indonesians are still internally colonized; they thus tend to glorify imported qualities 
over the indigenous ones. Even after its independence, Indonesians as ex-colonized are never free from the impact of colonization, thus profoundly influencing the cultural productions. In the cyberspace, excolonized are always the users, and never the inventors. Similarly, in the case of fashion, excolonized are always the followers, and never the trendsetters. The fact that fashion blog is a UCC, where bloggers have absolute freedom in creating any content as they like but still adhering to Western fashion bloggers, means that colonial remains embedded deeply in the minds of formerly colonized people.

\section{Acknowledgement}

The authors would like to extend a feeling of gratitude to Universitas Respati Yogyakarta, especially the Faculty of Social Sciences and Economics, for the supports that bring this article into fruition, Prof. Dr. Ida Rochani Adi, S.U. for the encouragement to explore the world of Popular Culture in the academe, and Laurence Joseph Splitter, BA(Hons Monash)., BPhil DPhil(Oxon) for the proofreads to refine this article.

\section{References}

Adi, I. R. (2016). "Taste and Values as Mechanism of Power: A Transnational Study on American Popular Culture" (Unpublished Research). Universitas Gadjah Mada, Yogyakarta.

AM, S. \& A.D. Lestariningsih (2017). Sejarah Indonesia: SMA/MA/SMK/MAK Kelas XI Semester 1. Jakarta: Kementrian Pendidkan dan Kebudayaan.

Badan Pusat Statistik. (2017). Suhu Minimum, Rata-Rata, dan Maksimum di Stasiun Pengamatan BMKG (oC). Badan Pusat Statistik. Retrieved from https://www.bps.go.id/statictable/2017 /02/09/1961/suhu-minimum-rata-ratadan-maksimum-di-stasiun-pengamatanbmkg-oc-2011-2015.html
Bhabha, H. K. (1994). The Location of Culture. New York: Routledge.

Berezhna, V. (2018). The Brand-Influencer Power Struggle. Business of Fashion. Retrieved from https://www.businessoffashion.com/arti cles/intelligence/the-brand-influencerpower-struggle.

Bressler, C. E. (2011). Literary Criticism: An Introduction to Theory and Practice. Boston: Longman.

Bullock, A., \& Stallybrass, O. (1977). The Fontana Dictionary of Modern Thought. London: Fontana Books.

Burney, S. (2012). Pedagogy of the Other: Edward Said, Postcolonial Theory, and Strategies for Critique. New York: Peter Lang.

Cawelti, J. (1977). Adventure, Mystery, and Romance: Formula Stories as Art and Popular Culture. Chicago: University of Chicago Press.

Corcoran, C. (2006). "The Blog that Took Over the Tent". Women's Wear Daily. Retrieved from http://wwd.com/fashion-news/ fashion-features/the-blogs-that-tookover-the-tents-547153/.

Cresswell, J. W. (2014). Research Design: Qualitative, Quantitative, and Mixed Methods. Approaches. New York: Sage.

de Brouwer, Z. \& Dekker, J. (2014). “Blogger Identity: A Portrait of Dutch Blogging Landscape." Arnhem: ArtEZ Institute of the Arts. Retrieved from https://www.artez.nl/media/studie_in_ci jfers/artez_fashion_masters_annual_repo rt_2014-2015_1_.pdf

Dean, J. (2010). Blog Theory: Feedback and Capture in the Circuits of Drive. Massachusetts: Polity Press.

Dhillon, K. (2018). What the Hell Are Resort and Cruise Collections and Why Are They So Lucrative?. High Snobiety. Retrieved from 
https://www.highsnobiety.com/2017/0 5/22/why-are-resort-cruise-precollections-important/.

Durmaz, L (2014). The Role of Social Media in the Fashion Industry: How Fashion Blogging Encourages Two-Way Symmetrical Communication. California Polytechnic State University. Retrieved from https://digitalcommons.calpoly.edu/cgi/ viewcontent.cgi?referer=https://www.go ogle.com $/ \&$ httpsredir $=1 \&$ article $=1081 \& \mathrm{c}$ ontext=joursp

Fanon, F. (2001). The Wretched of the Earth. London: Penguin

Fishkin, S. F. (2005). Crossroads of Cultures: The Transnational Turn in American Studies: Presidential Address to the American Studies Association, November 12, 2004. American Quarterly, 57(1), (1757). The Johns Hopkins University Press.

Held, D., \& A. McGrew. (2000). The Global Transformations Reader: An Introduction to the Globalization Debate. Cambridge: Polity Press/Blackwell.

Helton, R. (2002). Computers and the Digital Age. In M.T. Inge \& D, Hall (Eds.). The Greenwood Guide to American Popular Culture. (Volume Three, pp. 989-1017). Connecticut: Greenwood Press.

Hiddleston, J. (2009). Understanding Postcolonialism. Stocksfield: Acumen.

Jandrić, P. \& A. Kuzmanić. (2015). Digital Postcolonialism. IADIS International Journal on WWW/Internet, 13(2), 34-51. Retrieved from http://www.petarjandric. com/images/pdf/Jandric_Kuzmanic_jour nal.pdf.

Kraidy, M. (2002). Globalization of Culture through the Media. In J. R. Schement (Ed.), Encyclopedia of Communication and Information. (pp. 359-363). New York: Macmillan. Retrieved from http://repository.upenn.edu/asc_papers /325.
Kim, S. (1998). Cultural Imperialism on the Internet. The Edge: The E-Journal of Intercultural Relations, 1(4), 1-4.

Laric, O. (2010). Interview with Oliver Laric by Peter Nowogrodzki. INCITE: Journal of Experimental Media. Retrieved from http://www.incite-online.net/laric.html.

Lefebvre, H. (1991). The Production of Space. London: Blackwell.

Lopez y Royo, A. (2019). Contemporary Indonesian Fashion. New York: Bloomsbury.

McQuarrie, E. F., M. J. Miller, \& B. J. Philip. (2013). The Megaphone Effect: Taste and Audience in Fashion Blogging. Journal of Consumer Research, Inc., 40, 1-24. Retrieved from https://academic.oup. com/jcr/articleabstract/40/1/136/1792 230

Mead, G. H. (1967). Mind, Self \& Society from the Standpoint of a Social Behaviorist. Illinois: University of Chicago Press.

Ohiagu, O. P. \& V. O. Okorie. (2014). Social Media: Shaping and Transmitting Popular Culture. Covenant Journal of Communication, 2(1), 93-108. Retrieved from http://Journals.Covenantuniversity. Edu.Ng/Cjoc/Published/May2014/Obiag eli.Pdf

Onishi, N. (2010). As English Spreads, Indonesians Fear for Their Language. The New York Times. Retrieved from https://www.nytimes.com/2010/07/26/ world/asia/26indo.html.

Philpott, S. (2000). Rethinking Indonesia: Postcolonial Theory, Authoritarianism, and Identity. Hampshire: Macmillan Press Ltd.

Pustetto, M. (2011). 10 Tips to Planning Your Autumn/Winter Wardrobe. The Trend Spotter. Retrieved from https://www.thetrendspotter.net/10tips-planing-autumnwinter-wardrobe/. 
Quayson, A. (2000). Postcolonialism: Theory, Practice or Process. Malden, Massachusetts: Blackwell Publisher, Inc.

Ramutsindela, M. (2005). Parks and Peoples in Postkolonial Studies: Experiences in Southern Africa. New York: Kluwer Academic Publishers.

Risam, R. (2013). Decolonizing DH: Theories and Practices of Postcolonial Digital Humanities. Postcolonial Digital Humanities. Retrieved from https://dhpoco.org/blog/2013/04/12/d ecolonizing-dh-theories-and-practices-ofpostcolonial-digital-humanities/.

Rocamora, A. (2011). Hypertextuality and Remediation in the Fashion Media. Journalism Practice, 6(1), 92-106. http://dx.doi.org/10.1080/17512786.20 11.622914.

Rowe, J. C. (2014). Featured Articles: Three Articles on Transnationalism and American Studies. American Studies Association. Retrieved from http://www.theasa.net/project_eas_onlin e/page/project_eas_online_eas_featured_ article/

Shabazz, D. (1999). Internet Politics and the Creation of a Virtual World. International Journal on World Peace, XVI(3), 27-41.

Titton, M. (2015). "Fashion Personae: Selfidentity and Enactments of Fashion Narratives in Fashion Blogs". Fashion Theory, 19(2), 201-220. London: Bloomsbury Publishing PLC. https://www.tandfonline.com/doi/abs/1 0.2752/175174115X14168357992391

Toffler, A. (1980). The Third Wave. New York: William Morrow.

Tyson, L. (2006). Critical Theory Today: A User-Friendly Guide (2nd ed.). New York: Routledge.

Veblen, T. (1899). The Theory of the Leisure Class. New York: Macmillan.
Vetrovec, S. (1999). Conceiving and Researching Transnationalism. Ethnic and Racial Studies, 22(2), 1-25.

Whittaker, L. (2008). "Scotland's Shame": A Dialogical Analysis of the Identity of Young People Not in Education, Employment or Training. Psychology and Society, 1(1), 54-64.

Witjaksono, K. (2016). 5 Indonesian Fashion Influencers that will Inspire Your Wardrobe. Indonesian Tattler. Retrieved from https://indonesiatatler.com/fashionbeauty/fashion/5-fashion-influencersthat-will-inspire-your-wardrobe. 